\title{
Students' Social Literacy in their Daily Journal
}

\author{
Hafni Resa Az-Zahra ${ }^{\bowtie 1}$, Sarkadi2 \& Ishak G. Bachtiar ${ }^{3}$ \\ 1 Postgraduate Student of UNJ, Universitas Negeri Jakarta, Jakarta, Indonesia \\ 2,3 Lecture of UNJ, Universitas Negeri Jakarta, Jakarta, Indonesia \\ $\bowtie$ hafniresa07@gmail.com
}

\begin{abstract}
This study was aimed to determine the students' social literacy in their daily journals at grade four of Al-Fauzien Islamic elementary school in Indonesia. The ability of social literacy is the capacity of a person to be able to live and contribute to his or her community, which involved intellectual skills, social skills, cooperative skills, and attitudes and values. The student's daily journal is a collection of student writings whose contents expose students' skills in reflecting experiences, findings, critical thinking, connecting ideas, exploring and expressing their knowledge. The method used in this study is a qualitative method with qualitative content analysis techniques. The data of this study are the sentences taken from students 'daily journals, which were then reduced, coded based on students' social literacy aspects that appeared and analyzed, then triangulated. The results of the study revealed the ability of students' social literacy as follows: intellectual skills $34.1 \%$, social skills $12.6 \%$, cooperation skills $14.7 \%$, and social attitudes and values $38.5 \%$.
\end{abstract}

Keywords: Literacy, social literacy, student daily journal.

How to Cite: Az-Zahra, H., Sarkadi, S., \& Bachtiar, I. (2018). Students' Social Literacy in Their Daily Journal. Mimbar Sekolah Dasar, 5(3), 162-173. doi:http://dx.doi.org/10.17509/mimbar-sd.v5i3.12094.

INTRODUCTION The competency of education to be attained always develops and dynamic along with the current times. As in the $21^{\text {st }}$ century now, one issue that must be achieved through education is literacy skill. This lability is important to instill in education and is one of the competencies that must be achieved, because entering the $20^{\text {th }}$ century literacy has become a product as well as a goal set by the school that automatically makes the quality of individuals and groups determined by their literacy level (CookGumperz, 2006). The old definition of literacy has been expanded.

Literacy is not only interpreted as reading and writing literacy, but also involves one's skills in the context where literacy existed.
As stated by Bearne (2003, p. 98), "Literacy includes a set of cultural developments and contextually practiced in its culture". In short, literacy acquisition depends on the socio-cultural context where literacy is examined. Literacy is seen as a process of acquiring knowledge and skills in contributing for living such as developing socio-economic sector, building social care and critical reflection as the basis for individual change or social change (United Nations Educational \& Organization, 2008). From the above facts, it is recognized that literacy has become an ample viewpoint in education. A person who is literate does not only carry out his cognitive functions, but also affective and psychomotor. Hence, in literacy education, students are not only 
Hafni Reza Az-Zahra, Sarkadi, Ishak G. Bachtiar, Students' Social Literacy...

instilled to know about something, more than that students are taught to implement their knowledge in their lives, have values and behaviour originated in their values, so they can adjust themselves with life and create a harmony.

Good literacy skills can improve individual life quality, social groups, and even wider community (Cook-Gumperz, 2006). This denotes that the better the level of literacy, the higher the life quality will be. As literacy skill is important possed by individuals, then, it began to be learned from various discipline's perspectives so that the study of media literacy, scientific literacy, mathematical literacy, critical literacy was born, and one of them was social literacy.

Social literacy ability is a person's capability to integrate in implementing all knowledge, skills, including attitudes and values that he believes in social life. Social literacy involves the process of learning about a range of social skills as well as the development of social knowledge to understand and interpret various social problems that must be faced in life (Arthur \& Davison, 2000). Social literacy ability is a person's capacity to connect with people around, include social, intellectual, even emotional intelligence (Lgleysteen, 2018). From the above understanding, it can be concluded that social literacy is a capability that can be used by a person to live in the community and contribute to society, which involves various skills such as intellectual skills, social skills, cooperative skills, and attitudes and values.

Regarding the aspects of social literacy skills which include intellectual skills, social skills, cooperative skills and attitudes and social values, Jerolimek (1971) presents separate indicators for these four aspects. Intellectual skills include the ability to: a) identify and define issues, b) make hypotheses, write conclusions based on information, c) analyze and synthesize data, d) distinguish facts and opinions, e) formulate causal factors, f) submit opinions from different perspectives, g) make value judgment in making decisions. Social skills include the ability to: a) social sensitivity, b) control self, c) exchange ideas and experiences with others. Cooperation competences include the ability to: a) take roles in groups, b) participate in group discussions, c) participate in making group decisions. The attitudes and social values include: a) knowing common values that employed in the society, b) making decisions involving two choices based on value consideration, c) knowing guaranteed human rights for all citizens, d) developing loyalty as citizens, e) developing respect for the ideals and heritage of the nation, f) developing a sense of brotherhood among human beings. Thus, the scope of social literacy is not only possesing knowledge in solving social problems and issues, but also having social skills needed for living and solving all life's problems. Thereby, to be concluded, social literacy is a competence that can 
be used by someone to live in society and contribute to the community which involves various skills such as intellectual skills, social skills, cooperative skills, and attitudes and values.

In education, this social literacy ability emerged as a result of learning process, one of which is social studies learning, which is carried out in accordance with learning objectives. Social science is a subject taught in school filled by social science's material to achieve educational goals. This is similar to the opinion of Wesley (Supardan, 2015) that, "Social studies are the social sciences simplified pedagogical purpose." The National Council for Social Studies (Sapriya, 2015, p. 10) states, "Social study is integrated study of social sciences and humanities to promote civics' competencies." Thus, social studies consist of a series of social sciences taught in schools to support educational goals' achievement.

One school that is mindful of the importance of social literacy is Al-Fauzien Islamic elementary school in Depok, Indonesia. This awareness can be seen from the Student Profile expected by the school. The expected outputs of students' profile of this school are; religious Islamic students, lifelong learners, critical thinkers, problem solvers, collaborative students, and effective communicators. In its learning, Al-Fauzien school is not only instilled students to be able to construct knowledge, but students also taught to be able to implement the knowledge learnt in their daily lives so that the expected values and characters as outputs of learning could be manifested in their lives. In addition to learning, to create the expected student profile, this school also has various programs such as the Green School program, Life Skill, Show and Tell, Tilawati, and Writing Program. The writing program is integrated in learning and aims to create communicative students in writing. This writing program is presented in writing a daily journal as a reflection of the learning that has been done i.e. after discussing a theme in social studies learning. Student daily journals are collections of writings written by students whose contents reflect their skills in describing experiences, findings, critical thinking and connecting ideas, and making students to be able to explore and express their knowledge (Reinertsen \& DaCruz, 1996).

For these reasons, the students' social literacy skills are interesting and important to be analyzed further through their daily journal. The reason is because students' social literacy abilities show the ability of students in implementing the skills and knowledge they have as a follow-up to their social cognition. By knowing the existence of social literacy skills in students, it will also be known how students perceive themselves as an integral part of society and have to contribute to society.

Therefore, based on the description of the above paragraph, there is a need for a deeper study of the ability of students' 
Hafni Reza Az-Zahra, Sarkadi, Ishak G. Bachtiar, Students' Social Literacy...

social literacy, especially at Al-Fauzien Islamic elementary school. Therefore, the researcher intends to conduct a research on social literacy skills in students' daily journals. The research is a qualitative content analysis study. The researcher hopes that this research, as the feed back, will give some benefits to the school. Meanwhile, the focus of the problem in this study is "How is the ability of social literacy skills in their daily journals of the sixth-grade students of Al-Fauzien Islamic Elementary School?" In the detail, the focus is synthesized into the following sub-focus.

1. How are students' intellectual skills in their daily journal?

2. How are students' social skills in their daily journal?

3. How are the students' cooperative skills in their daily journal?

4. How are the attitudes and values of students in their daily journals?

\section{METHODS}

This research is a qualitative research by using qualitative content analysis techniques. (Krippendorf, 2004, p. 10) suggests, "Content analysis is a research method to draw inferences from content of communication that appears to be done in a valid, reliable, and replicable manner." Meanwhile, Berelson (Neuendorf, 2016, p. 18) suggests, "Content analysis is a research technique to describe accurately, systematically and quantitatively about the content of visible communication." Thus, content analysis is a research method to describe data that is objectively studied by researchers in a systematic way through particular stages then the final results are presented in the form of a percentage table.

This research was conducted in the fifth grade of Al-Fauzien Islamic elementary school in Indonesia, during second semester from January to March 2018. Data in this study were obtained from students' writing in daily journals that related their learning activities in schools, teacher interviews, and observations on students during their learning. The student daily journals analyzed belonged to 24 students in which each of them wrote five journals.

\section{RESULTS AND DISCUSSION}

The four aspects of social literacy skills of the students appeared in the journal are described as follows: the intellectual property appeared 116 times, social skills as many as 43 times, cooperation skills 50 times while the attitudes and social values appeared 131 times. The total appearance is 340 times. In details, the aspects of social literacy capabilities appeared can be seen in the Table 1.

Table 1. Frequency of Appearance of Students' Social Literacy Ability in Daily Journals

\begin{tabular}{lcc}
\hline \multicolumn{1}{c}{ Aspects of Social Literacy Ability } & Frequency & Percentage \\
\hline I. Intellectual skills & & 13 \\
\hline The ability to identify and define issues & 36 & $34,1 \%$ \\
Make a hypothesis; write conclusions based on information & 19 & \\
Analyze and synthesize data & 20 &
\end{tabular}


Formulate causal factors

11

Submit opinions from different perspectives

7

Make value judgments in making decisions $\quad 10$

Total Intellectual Skills

116

\begin{tabular}{lc}
\hline II. Social skills & \\
\hline Live in harmony and work together; respect others' rights, & 24 \\
have social sensitivity & 8 \\
Learn to control self & 11 \\
Exchange ideas and experiences with others & 43 \\
Total Social Skills & $12,6 \%$ \\
\hline III. Cooperation Skills & 23 \\
\hline Taking roles in group & 6 \\
Participating in group discussions & 20 \\
Participating in making group decisions & 50 \\
Total Cooperation Skills & \\
\hline IV. Social attitudes and values & 21 \\
\hline Knowing the general values that implemented in society & 24 \\
Making a decision that involves two choices based on the & $14,7 \%$ \\
value & 20 \\
Knowing guaranteed human rights for all citizens & 24 \\
Developing loyalty as a citizen & 18 \\
Developing respect for national ideals and heritage & 24 \\
Developing sense of brotherhood among humans & 131 \\
Total Attitude and Social Valves & 340 \\
\hline Total Overall Aspects of Social Literacy & $38,5 \%$ \\
\hline
\end{tabular}

Based on Table 1 above, it can be seen that from the total percentage, students' social literacy skills were distributed as follows: intellectual skills is $34.1 \%$, social skills is $12.6 \%$, cooperation skills is $14.7 \%$, and attitudes and social values is $38.5 \%$. The attitudes and social values obtained the highest percentage. The detail is described as follows:

\section{Intellectual Skills of Four Grade Students in}

\section{Daily Journal}

Intellectual skill is a mental operation that allows a person to acquire knowledge, apply knowledge, and control mental processes (Johnson, 1997). Based on Table 1 , it can be seen that students 'intellectual skills appear 116 times in students' daily journals. This appearance represents $34.1 \%$ of all aspects of social literacy skills. The discussion is as follows:
The ability to identify and define issues arises when the teacher gave the task of observing and interviewing students on the examples of globalization in the community. When the teacher did it, learning became compatible with constructivism learning concepts that motivate the students to become subjects of active learning who can do problem solving, work in small groups, collaborative, investigative, and experimental (Jacobsen, Eggen, \& Kauchak, 1999). By learning based on experience, students are required to be able to see things that happen directly in the community, so students will better recognize, understand and be able to define the occurring current issues and problem. The impact of learning based on experience can be interpreted as a sustainable learning activity, since they always interact directly with the world as well as keep in contact 
Hafni Reza Az-Zahra, Sarkadi, Ishak G. Bachtiar, Students' Social Literacy...

with real problems that continue to appear together with the previous experiences (Jacobsen et al., 1999).

The ability to draw conclusions was seen when students concluded the results of their observations and interviews on the example of globalization in the community. With such learning activities, students were stimilated to think critically so they can draw a conclusion. As stated by Dwijananti and Yulianti that the conclusion process starts from organized mental processes by analyzing, interpreting data, and discussing based on scientific inquiry learning (Dwijananti \& Yulianti, 2010).

Students' ability to analyze and synthesize data was seen when students described positive and negative effects of junk food and gadgets on health based on the articles, they read during their learning. As stated by Agustyaningrum, the ability of synthesis analysis is the ability to examine and interpret information and compile or merge the amount of information given to construct new information (Agustyaningrum, 2015). In other words, the ability of synthesis analysis involves the process of interpretation by linking or uniting various elements so that a more comprehensive pattern is formed (Sanderayanti, 2015). In this case, the students can describe the bad effects that occur when someone consumes junk food and uses the gadget excessively so that students can create new patterns that in addition have a positive impact, it turns out that junk food, and gadgets also have a negative impact on society.

The ability to distinguish facts and opinions is actually aided by understanding and students' previous learning experiences regarding differences in facts and opinions. Some students who red the articles about the positive and negative effects of junk food and gadgets on health contained a fact because there were already survey results showed in the article. While other students trusted the article since they have undergone the case in the article. When students assess something based on the data and the experience occurred, students actually have done an evaluation process because students have tried to give opinions based on certain criteria (facts or opinions) and make judgments and considerations based on reasoning (Sanderayanti, 2015).

The ability of students to form causal relationships began to when they were seven years old. At that age, they begin to be able to assess causal relationships, start using mental operations to solve concrete problems and allow the process of memory recall in the form of understanding (Papalia, Olds, \& Feldman, 2007). Learning with a scientific approach that centered on students in grade four when discussing examples and the impact of globalization in society has involved many mental operations of students in solving problems and developing students' ability to analyze. The effect of analytical 
skills made them be able to examine and analyze information by sorting out causes and effects (Agustyaningrum, 2015). Thus, it is reasonable if the students 'ability in formulating causal relationships appeared in students' daily journals because when the previous learning about globalization in which student-centered approach used, they also have obtained the ability to carry out the analyzes.

The ability of students to submit opinions from different perspectives also arose when students learned from the examples of globalization in society. At that time, the students were given the task to interview the people around them on the example of globalization issue. The interview results were then discussed with other friends who also chose the same issue. Some students did not agree with the answers of the majority, so they expressed their disagreement in their daily journal. The ability of students to express diverse opinions is indeed very much needed so that all existing ideas or opinions are accommodated regardless of their positive or negative in nature (Sapriya, 2015). If in their learning processes students are accustomed to expressing ideas or opinion, students will be trained to dare to speak and think critically. As Sapriya stated that the purpose of critical thinking is to test an opinion or idea, including making judgments based on the opinions proposed (Sapriya, 2015).

Students ability to make value judgments in making decisions appeared in students' daily journals when students chose appropriate sources to be observed and interviewed about examples of globalization in society. Looking at the findings of the research, it seems that the values that are taken into consideration by students in making decisions are substantive values. Substantive value comes from beliefs held based on processes understanding, institutions and authorization that practiced in society (Sapriya, 2015). In this case, the substantive value that is taken into consideration is the values underlying the status, role and inclination of a person in their family institution.

\section{Social Skills of Grade Four Students in the Daily Journal}

Elliot \& Gresham (Rao, Beidel, \& Murray, 2008) explain, social skills as specific behaviors that are produced in positive social interactions, and are needed for effective interpersonal communication. The impact of social skills that include certain attitudes found in a person can be used for a success in the social domain or social relations (Gresham, Sugai, \& Horner, 2001). The discussion on students' social skills is explained as follows.

Social sensitivity of students was identified when learning about natural disasters, i.e. when students felt sad to see the video of the victims of the Mount Sinabung natural disaster. When students showed their social sensitivity, they were actually showing their emotional intelligence. Emotional 
Hafni Reza Az-Zahra, Sarkadi, Ishak G. Bachtiar, Students' Social Literacy...

intelligence includes the ability to empathize and be sensitive to the feelings of others (Goleman, 2000). This social sensitivity is important to be fostered and trained as it is the basic point of student success. The learning activity that showed videos about natural disasters which were currently happening is not only contextual learning but also fostering students' social sensitivity as this video can stimulate the amygdala of the brain that controls emotions (Rose \& Nicholl, 1998). If the amygdala does not function, the creative, imagination and emotional nuances that move feelings of art, humor, imagination, affection, music, and a sense of humanity will diminish (Jensen, 1995). Thus, learning that motivate performance is virtuous to develop students' social sensitivity.

Students' ability to control self is naturally seen in elementary school students. Around the age of eleven years, children have been able to describe conflicting feelings towards the same target even at the age of eight years children begin to be able to integrate a series of positive and negative emotions that are mutually opposed at one time (Papalia et al., 2007). However, all this goes back to the emotional intelligence possessed by the students. Students who are able to manage self-emotions have an awareness of the emotions they feel. Emotion awareness can fortify them from negative behaviors when expressing emotions that they feel (Goleman, 2000). Then in this case the role of the teacher is also very helpful in teaching students about self control. From interviews with teacher and the writing in the students' daily journals it is known that the teacher sometimes invites students to discuss and solve problems existed. This can reduce the chance of fights that arise because students were indirectly taught to express anger verbally rather than physically through communication and deliberation (Jacobsen et al., 1999). Thus, group learning will always allow conflict, but the emotional intelligence of students in controlling their negative emotions and the role of the teacher as a mediator of conflict will help to solve problems without fighting.

From group learning, students have developed skills in exchanging ideas and experiences with others. In the lesson, this is important to do considering that by doing so students will be helped to see ideas in different ways and allow students to construct knowledge by empowering other people's ideas (Jacobsen et al., 1999).

\section{The Collaboration among Grade Six Students in their Daily Journal}

Cooperation according to Arifin (2015, p. 58 ) is "a skill in which there are certain activities to achieve common goals by helping each other and understanding each other's activities". Division of roles in groups is one of the most important parts of collaboration process. In detail 
discussion of student cooperation skills is as follows.

Based on content analysis in students' daily journals, it appears that students each has their role in the group for a goal to be achieved together i.e. to be the winner of the "Labirint Goals" game. Group learning carried out through games can indeed improve cooperation skills (Indrastoeti \& Mahfud, 2015). So that clearly in daily journals, students express one of the forms of cooperation that they do with friends is to share roles in the game and try to carry out their roles skillfully for a victory.

Cooperation will arise if a person has knowledge and self-control to fulfill the goal through cooperation (Arifin, 2015). Knowledge that students have was shown when students hold discussions in the process of group collaboration. Thus, students were seen participating in group discussions by exchanging their knowledge.

In addition, student participation in making group decisions also appeared when they were given quizzes about globalization. The quiz has been able to involve cognitive aspects (problem solving) and psychomotor aspects (cooperation skills) because the teacher actually asks ordinary questions, but rather than calling one student, the teacher asks all students to think about the answer (thinking aspect) then discuss it with them (sharing aspect) (Jacobsen et al., 1999). Thus, learning becomes more effective because all students were actively involved in making group decisions to answer the quiz.

\section{Attitudes and Values of Grade Six Students in their Daily Journal}

The attitudes and social values of students appeared $38.5 \%$ in students' daily journals. This number shows the ability of students' attitudes and social values to be the highest social literacy aspect that appears in daily journals. The discussion is as follows

Students are already familiar with the values that generally practiced in society i.e. religious values that distinguish between halal and haram, health values that distinguish between healthy and unhealthy and economic values that distinguish profitable and unprofitable. These values become a reference in behaving and acting done by students in the community (Jacobsen et al., 1999).

Students are able to take decisions involving two choices based on value considerations. Decision making is part of cognitive skills that involve the development and application of procedures to organize, select, and interpret information in a decision context (Ross, 1981). However, it is not enough just to use cognitive abilities. The more comprehensive decision making is the ability to think about available alternative choices, considering existing facts and evidence, considering personal and community values (Sapriya, 2015). Looking at the students' exposure in the journal, it seems that learning by watching videos of 
Hafni Reza Az-Zahra, Sarkadi, Ishak G. Bachtiar, Students' Social Literacy...

export- import activities, students have knowledge on healthy and unhealthy products and have strong religious values, so when they find out there are unclean and unhealthy imported products they immediately decide not to consume and use the products.

Students also know human rights guaranteed for all citizens. In learning the topic of natural disasters, the students know that basically all human beings are created equal i.e. having natural similarities in the form of reason, mind, feeling and will as characteristic of human beings who are cultured and humane (Muhammad, 2005). Besides that, it seems that the teacher also performs his role well by giving students questions that lead to human values. As part of a multicultural Indonesian society, differences in religious and cultural values do exist but what teachers must not forget is to teach universal values that apply to all humans (Sapriya, 2015). Included in this statement is to teach students about the natural values of humans in the midst of existing cultural and religious values. In addition, based on the teacher's answers in the interview, students' understanding of human values also helped from the learning of Citizenship Education. This is indeed in line with what was stated by Arthur and Davison that social literacy ability not only arose from learning about the social sciences but also through civics' education (Arthur \& Davison, 2000).
When students learn about domestic and foreign products, it was seen in the journal students that they also have a loyal attitude towards Indonesian products. Social studies learning can increase students' love for the nation and Indonesia, and if it is deepened it will develop into a loyalty.

There are four elements of ways of life i.e. ideals, virtues, effort, trust or confidence. Ideals are something that is a desired be achieved in the struggle (Muhammad, 2005). As stated in the opening of the 1945 constitution, the aspirations of the Indonesian people are the unity of the entire Indonesian nation amid the diversity and nurture multiculturalism. It is undeniable that Indonesia is a multicultural country so that the nation's motto is 'Unity in Diversity'. From the explanation of the students' sentences in the journal, it seems that the students have understood the meaning of the motto "Bhineka Tunggal Ika" so that students want to help victims of natural disasters despite their different religion and different culture.

Based on what students do and describe in their daily journals, students give attention and care for others. This is actually the most important part of social literacy where students not only understand existing social issues or problems but also participate in building communities and help solving social problems by participating directly in the communities where they live (Arthur \& Davison, 2000). However, the important 
thing that should not be overlooked from social participation activities is that activities involving students must have reciprocal effect for both students and the community. The activities carried out supported by other parties as long as their activities are positive, and the activities must develop intellectually, student ethics and morals. Based on the results of the observations, what the student described in the journal is true because besides expressing their intentions to help, the students also immediately raised funds for the victims, and the school participated in supporting the activity.

\section{CONCLUSION}

Social literacy ability is someone's capacity that involves intellectual skills, social skills, cooperative skills and attitudes and values to socialize and contribute to their social environment. Social literacy skills can be developed through social studies learning and citizenship education. Students' social literacy skills that involving intellectual skills will emerge during teaching and learning processes rooted in a constructivism approach in which students act as active learner. Social skills and cooperative skills will emerge when learning is organized with group learning methods, while social attitudes and values emerge as the impact of students' social knowledge and skills that hold firmly and implemented in their daily social life.

\section{REFERENCES}

Agustyaningrum, Mengembangkan

N. (2015). Keterampilan
Berpikir Tingkat Tinggi dalam Pembelajaran Matematika SMP. PYTHAGORAS: Jurnal Program Studi Pendidikan Matematika, 4 (1).

Arifin, B. S. (2015). Psikologi Sosial. Bandung: Pustaka Setia.

Arthur, J., \& Davison, J. (2000). Social literacy and citizenship education in the school curriculum. Curriculum Journal, 11 (1), 9-23.

Bearne, E. (2003). Rethinking literacy: Communication, representation and text. Reading, 37(3), 98-103.

Cook-Gumperz, J. (2006). The social construction of literacy (Vol. 25): Cambridge University Press.

Dwijananti, P., \& Yulianti, D. (2010). Pengembangan kemampuan berpikir kritis mahasiswa melalui pembelajaran problem based instruction pada mata kuliah fisika lingkungan. Jurnal Pendidikan Fisika Indonesia, 6(2).

Goleman, D. (2000). Kecerdasan emosional: Gramedia Pustaka Utama.

Gresham, F. M., Sugai, G., \& Horner, R. H. (2001). Interpreting outcomes of social skills training for students with highincidence disabilities. Exceptional children, 67(3), 331-344.

Indrastoeti, J., \& Mahfud, H. (2015). Pembelajaran Kooperatif Dengan Pendekatan Experiental Learning Untuk Meningkatkan Keterampilan Sosial. Mimbar Sekolah Dasar, 2(2), 140-151.

Jacobsen, D. A., Eggen, P. D., \& Kauchak, D. P. (1999). Methods for teaching: Promoting student learning: Merrill Upper Saddle River, NJ.

Jensen, E. (1995). Brain-based learning \& teaching: Brain Store Incorporated.

Jerolimek, J. (1971). Social studies in elementary education. In. New York: The Macmillan Company. 
Hafni Reza Az-Zahra, Sarkadi, Ishak G. Bachtiar, Students' Social Literacy...

Johnson, S. D. (1997). Learning technological concepts and developing intellectual skills. In Shaping Concepts of Technology (pp. 161-180): Springer.

Krippendorf, K. (2004). Content Analysys An Introduction to Its Methodology 2nd Edition. London: Sage Publication.

Lgleysteen. (2018). Social Illiteracy. Retrieved from http://serendip.brynmawr.edu/excha nge/ed-250-literacies-andeducation/Igleysteen/social-illiteracy

Muhammad, A. (2005). Ilmu Sosial Budaya Dasar. PT. Citra Aditya Bakti.

Nevendorf, K. A. (2016). The content analysis guidebook: Sage.

Papalia, D. E., Olds, S. W., \& Feldman, R. D. (2007). Human development: McGraw-Hill.

Rao, P. A., Beidel, D. C., \& Murray, M. J. (2008). Social skills interventions for children with Asperger's syndrome or high-functioning autism: A review and recommendations. Journal of autism and developmental disorders, 38(2), 353-361.

Reinertsen, P., \& DaCruz, G. (1996). Using the daily newspaper and journal writing to teach large introductory sociology classes. Teaching Sociology, $24(1), 102-107$.

Rose, C. P., \& Nicholl, M. J. (1998). Accelerated learning for the 21st century: The six-step plan to unlock your master-mind: Dell Books.

Ross, J. A. (1981). Improving adolescent decision-making skills. Curriculum Inquiry, 11 (3), 279-295.

Sanderayanti, D. (2015). Pengaruh Motivasi Berprestasi dan Kemampuan Berpikir Kritis Terhadap Hasil Belajar Matematika Siswa di SDN Kota Depok. Jurnal Pendidikan Dasar, 6(2), 222-231.

Sapriya. (2015). Pendidikan IPS. Bandung: PT. Remaja Rosdakarya.
Supardan, D. (2015). Pembelajaran IImu Pengetahuan Sosial: Perspektif Filosofi dan Kurikulum. Jakarta: Bumi Aksara.

United Nations Educational, S., \& Organization, C. (2008). Education for all: Global monitoring report. In: UNESCO Paris, France. 